\title{
Pengembangan dan analisis kualitas sistem monitoring kegiatan belajar mengajar siswa tingkat sekolah menengah atas negeri di jombang
}

\section{Development and analysis of the quality of the monitoring system of the teaching and learning process at a public senior high school in Jombang}

\author{
Fajar Indra Kurniawan a, Ronny Makhfuddin Akbar b \\ $a, b$ Teknik Informatika, Universitas Islam Majapahit, Mojokerto, Indonesia \\ email:afajar@unim.ac.id,bronnyma.ft@unim.ac.id
}

\begin{tabular}{l}
\hline I N F O A R T I K E L \\
\hline Sejarah artikel: \\
Menerima 9 Mei 2020 \\
Revisi 20 Juni 2020 \\
Diterima 21 Juni 2020 \\
Online 27 Juni 2020 \\
\hline
\end{tabular}

Kata kunci:

efficiency

reliability

sistem monitoring

usability

WebQEM

Keywords:

efficiency

monitoring system

reliability

usability

WebQEM

\footnotetext{
Style APA dalam menyitasi artikel ini:

Kurniawan, F. I., \& Akbar, R. M. (2020). Pengembangan dan analisis kualitas sistem monitoring kegiatan belajar mengajar siswa tingkat sekolah menengah atas negeri di Jombang.
}

\begin{abstract}
Monitoring siswa merupakan bentuk proses pengawasan sekolah terhadap kegiatan belajar mengajar siswa, salah satunya di tingkat Sekolah Menengah Atas Negeri atau SMAN Mojoagung, Jombang, Jawa Timur, Indonesia. Monitoring siswa tersebut meliputi jurnal kelas, presensi siswa dan capaian kompetensi dasar siswa. Proses pengolahan monitoring yang berjalan selama ini memiliki beberapa kendala, diantaranya 1) Belum tersedianya rekapitulasi absensi per mata pelajaran, sehingga guru mata pelajaran kesulitan memonitor kehadiran siswa ketika mata pelajaran sedang berlangsung; dan 2) Tidak terdokumentasi dengan baik capaian kompetensi dasar yang telah diajarkan pada tiap mata pelajaran, yang akhirnya mempengaruhi kualitas proses belajar mengajar. Berdasarkan kendala yang dialami, perlu dibangun sebuah sistem informasi yang mampu mengakomodasi pengelolaan proses aktivitas belajar mengajar meliputi pelaporan jurnal kelas, rekapitulasi absesi kehadiran siswa per mata pelajaran, dan laporan capaian kompetensi dasar. Pengembangan sistem informasi pada penelitian ini menggunakan Waterfall. Sistem monitoring ini menggunakan tiga aspek pengujian, diantaranya efficiency, reliability, dan usability berdasarkan Web Quality Evaluation Method (WebQEM). Hasilnya menunjukkan rata-rata loadtime 2,78 detik dan rata-rata pagesize 190,52 KB pada kecepatan internet 20,98 Mbps, serta persentase session, pages dan hits dengan nilai 99\% dengan 25 data pada pengujian efficiency. Pengujian reliability menunjukkan performa yang baik karena mampu mengakomodasi 600 user yang menangani 1.085 request dan throughput 227,098/menit dengan 0\% error dari total 5.322 data yang tersimpan. Sedangkan pengujian usability yang melibatkan 322 responden memiliki persentase $76,72 \%$ yang masuk kategori baik. Dari hasil pengujian tersebut aplikasi mampu menangani permintaan data dalam jumlah besar dan memastikan kehandalan server mengakomodasi akses seluruh siswa SMAN Mojoagung.
\end{abstract}

\section{ABSTRACT}

Student monitoring is the form of school's supervision process on the teaching and learning activities at SMAN Mojoagung, Jombang, East Java, Indonesia, which includes the class journals, student's attendance, and students' achievement of basic competencies. However, the recent monitoring process has had some obstacles, including 1) The absence of recapitulation of students' attendance in each lesson which makes it difficult for the teacher to monitor the students' attendance in the teaching and learning process; and 2) 

which ultimately affects the quality of the teaching and learning process. Based on the obstacles, it is crucial to build a web-based information system which is capable to accommodate the supervision process of the teaching and learning activity involving class journal report, recapitulation of the students' attendance in each lesson and the report of basic-competence achievement. The approach of this current research in this information system development used Waterfall method. The approach of this current research in this information system development used Waterfall method. The developed monitoring system used three aspects of testing, including efficiency, reliability, and usability based on the Web Quality Evaluation Method (WebQEM). The results showed an average loadtime of 2.78 seconds and an average pagesize of $190.52 \mathrm{~KB}$ at $20.98 \mathrm{Mbps}$ internet speed as well as a percentage of sessions, pages, and hits of $99 \%$ in the efficiency testing on 25 data. The reliability testing showed proper performance since it could accommodate 600 users which handle 1,085 Request and 227.098/minute Throughput with 0\% Error from the total of 5,322 saved data. Meanwhile, the usability testing involving 322 respondents showed a percentage of $76.72 \%$ and were categorized as good. Based the test results, the application was able to handle a large amount of data demand and ensured the reliability of the server in accommodating the access to all students of SMAN Mojoagung. Teknologi: Jurnal IImiah Sistem Informasi dengan lisensi CC BY NC SA.

\section{Pendahuluan}

Belum terakomodasinya monitoring absensi per mata pelajaran dan kompetensi dasar pembelajaran pada setiap aspek kegiatan proses pelajar mengajar dan belum adanya sistem monitoring berjenjang per tahun pelajaran yang memudahkan kepala sekolah di SMAN Mojoagung Jombang Jawa Timur, menyebabkan bertumpuknya dokumen-dokumen adminitrasi akademik sehingga membutuhkan waktu yang relatif lama dalam proses pencarian data dan pengelolaan lainnya, terlebih seluruh dokumen dalam bentuk kertas, salah satunya adalah jurnah kelas. Jurnal kelas berbentuk buku yang berisi informasi kehadiran siswa dan kompetensi dasar yang sudah diajarkan oleh guru mata pelajaran. Informasi tersebut dituliskan secara deskriptif setiap hari pada buku jurnal kelas dan dikumpulkan setiap semester, sehingga membutuhkan waktu lama untuk melakukan rekapitulasi data, hal tersebut selama ini menjadi kendala di SMA Negeri Mojoagung. Di sisi lain, untuk mengetahui siapa siswa yang belum hadir pada jam pertama dilakukan secara manual per kelas, sehingga menjadi permasalahan guru piket melakukan pelaporan harian.

Beberapa penelitian terkait dengan pengembangan sistem informasi monitoring diantaranya adalah 1) Putri dan Wulandari (2016) yang mengusulkan sistem informasi monitoring berbasis web dan SMS gateway. Sistem yang diusulkan Putri dan Wulandari (2016) berhasil memudahkan sekolah, siswa, orang tua atau wali siswa untuk mendapatkan informasi yang jelas dan cepat penyampaiannya. Namun, pada usulan Putri dan Wulandari (2016) belum terdapat pengelolaan capaian kompetensi dasar; 2) Sari, Remawati, dan Widada (2017) mengusulkan sistem informasi monitoring guna memantau proses belajar mengajar siswa, sistem tersebut hanya berdasarkan hasil evaluasi belajar; 3) Utomo (2017) mengusulkan sistem pemantauan siswa yang memudahkan pihak sekolah dalam memantau, mengontrol absensi dan informasi nilai akademik siswa secara mudah, dan cepat tanpa harus membuka buku besar. Namun, fitur absensi pada usulan Utomo (2017) hanya pada absensi harian dan belum mengakomodasi absensi per mata pelajaran; dan 4) Sutinah, Azima, dan Imaduddin (2018) mengusulkan sistem informasi monitoring guna proses integrasi data akademik yang mampu menghasilkan laporan akademik, tetapi sistem yang diusulkan belum tersedia pengelolaan capaian kompetensi dasar absensi per mata pelajaran serta jurnal kelas. Keempat penelitian yang telah disebutkan menggunakan blackbox testing sebagai pengujian sistemnya yang berfokus pada keperluan fungsional dari perangkat lunak.

Sedangkan penelitian yang menggunakan pegujian Web Quality Evaluation Method (WebQEM) juga pernah dilakukan oleh beberapa peneliti, diantanya adalah 1) Yaqin (2019) menggunakan pengujian eficiency dan realibility pada sistem informasi monitoring bidikmisi yang memiliki fitur laporan pembayaran kuliah per semester, perkembangan IPK, dan prestasi mahasiswa bidikmisi Simtem yang diusulkan Yaqin (2019) menggunakan prototype; 2) Sari (2016) melakukan analisis kualitas functionality, efficiency, reliability, dan usability yang hanya berorientasi pada pengguna terhadap sistem yang sedang 
dikembangkan, yaitu sistem informasi akademik berbasis web; 3) Hakim, Saragih, dan Suharto (2015) melakukan analisis menggunakan WebQEM untuk mengetahui kualitas aplikasi ujian online berbasis web; dan 4) Kartiko dan Hertantyo (2018) menggunakan WebQEM guna mengukur, apakah ada peningkatan kualitas terhadap aplikasi pemantau media sosial dan media daring yang telah diusulkan.

Berdasarkan latar belakang masalah dan state of the art yang telah dipaparkan, belum terakomodasinya pengelolaan proses aktifitas belajar mengajar yang meliputi pelaporan jurnal kelas, rekapitulasi absesi kehadiran siswa per mata pelajaran dan laporan capaian kompetensi dasar. Maka pada penelitian ini diusulkan pengembangan sistem informasi monitoring siswa dengan fitur yang sesuai kebutuhan SMAN Mojoagung dengan menggunakan pengujian WebQEM. Tujuan penelitian ini adalah dengan adanya sistem informasi monitoring siswa dapat memenuhi pengelolaan proses aktifitas belajar mengajar yang meliputi pelaporan jurnal kelas, rekapitulasi absesi kehadiran siswa per mata pelajaran dan laporan capaian kompetensi dasar. Sehingga hasilnya nanti dapat digunakan untuk membantu dan memudahkan pihak sekolah dalam mengambil keputusan terkait dari hasil studi siswa di sekolah.

\section{Metode Penelitian}

Pengembangan sistem informasi yang digunakan pada penelitian ini adalah Waterfall. Tahapan waterfall pada penelitian ini diilustrasikan pada Gambar 1, sedangkan penjelasan pada Gambar 1 disajikan sebagai berikut:

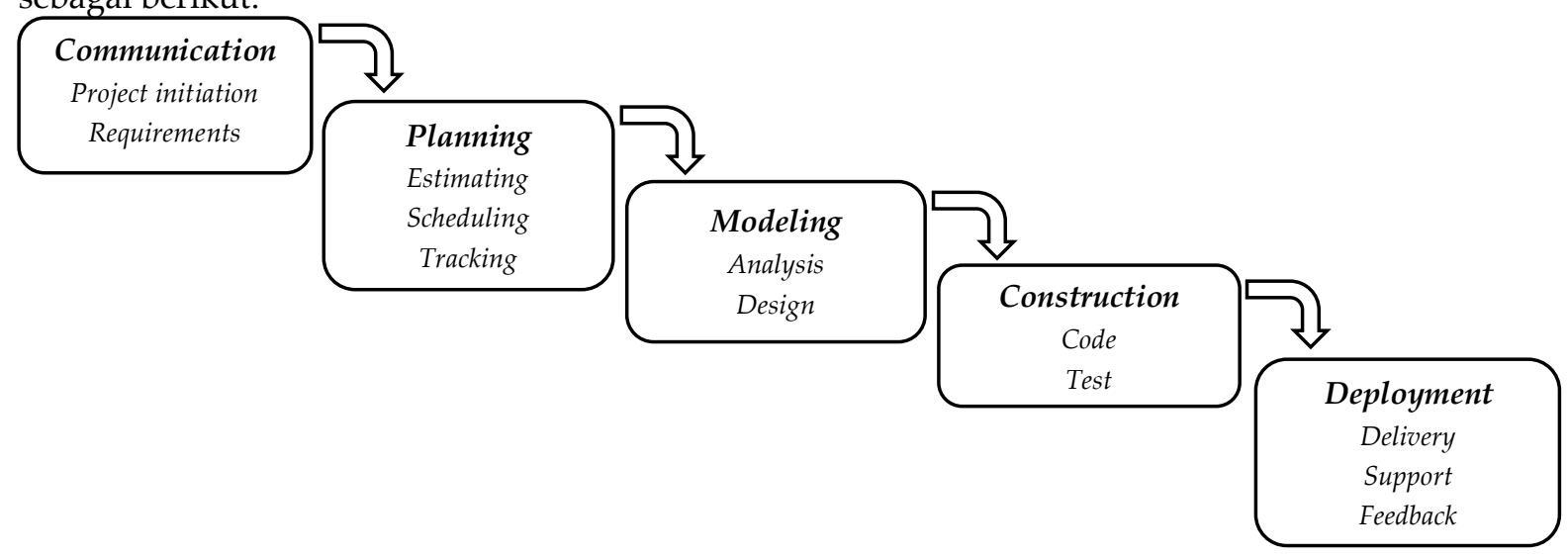

Gambar 1. Model waterfall (Pressman \& Maxim, 2015)

\subsection{Communication}

Pada tahap ini dilakukan komunikasi dengan klien untuk memahami sistem yang ingin dicapai. Hasil dari komunikasi dapat dalam bentuk pengumpulan data, baik melalui observasi langsung maupun wawancara. Hal tersebut guna untuk menyepakati fokus permasalahan yang akan diselesaikan, fitur apa yang ditawarkan, tujuan apa yang ingin dicapai sejak awal. Sehingga dapat dianalisis kebutuhan apa saja yang diperlukan baik kebutuhan fungsional maupun kebutuhan nonfungsional. Penelitian ini mengusulkan untuk melakukan pengembangaan sistem monitoring siswa. Hasil dari komunikasi didapatkan proses bisnis yang sedang berjalan, seperti yang disajikan pada Gambar 2, sedangkan Gambar 3 ilustrasi proses bisnis yang diusulkan pada penelitian ini.

Kebutuhan fungsional sistem monitoring siswa berdasarkan analisis kebutuhan adalah sebagai berikut:

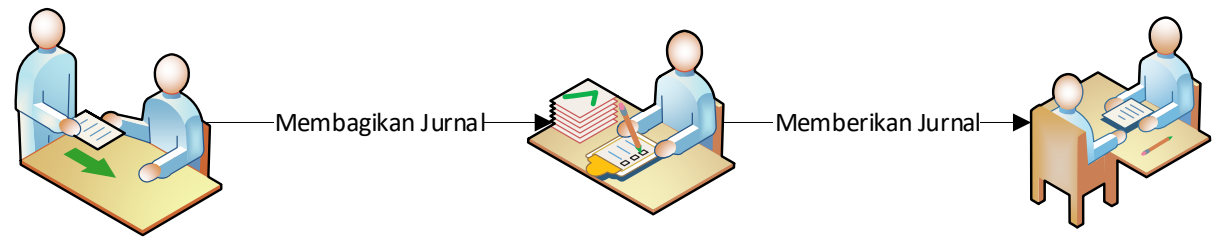

Waka Kurikulum

Membagikan Jurnal di Setiap Kelas
Guru

Mengisi Jurnal Kelas
Waka Kurikulum

Rekapitulasi Kehadiran Guru dan Kompetensi Dasar

Gambar 2. Proses bisnis yang sedang berjalan 


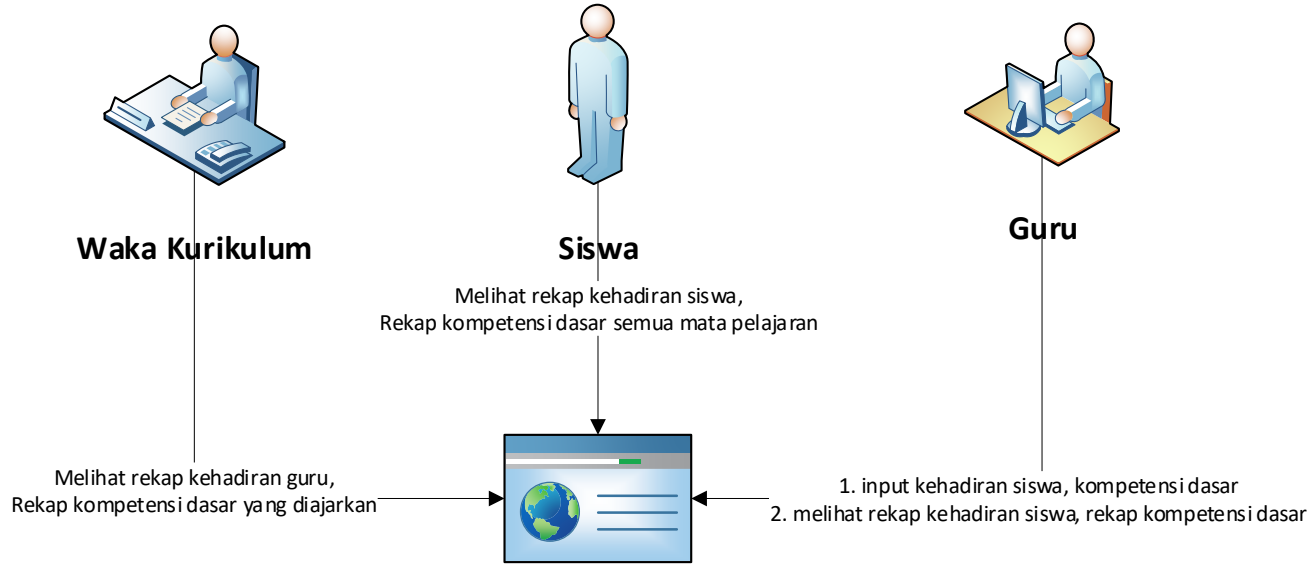

Sistem Monitoring Siswa

Gambar 3. Proses bisnis yang diusulkan

1. Dashboard berupa halaman depan portal.

2. Master berisi data tahun pelajaran, data siswa dan guru, data kelas, serta data mata pelajaran.

3. Akademik berisi dataset Kompetensi Dasar (KD), tugas mengajar, guru piket, ketua kelas, wakil kepala kurikulum, dan kenaikan kelas.

4. Pengguna berupa data pengguna guru dan siswa.

5. Jurnal berupa data capaian kompetensi dasar yang diajarkan.

6. Absensi siswa berisi cek kehadiaran siswa per kelas dan per mata pelajaran.

7. Rekap absensi siswa berupa rekapitulasi kehadiran siswa .

8. Wakakur adalah data wakil kepala sekolah bidang kurikulum untuk memantau guru mata pelajaran.

9. Evaluasi Kegiatan Belajar Mengajar (KBM) berupa import nilai dalam bentuk Microsoft Excel ke dalam sistem

Sedangkan kebutuhan nonfungsional sistem monitoring siswa berdasarkan analisis kebutuhan adalah perangkat keras, perangkat lunak, jaringan internet, pengguna, dan basis data. Spesifikasi perangkat keras yang digunakan oleh administrator dan pengguna agar dapat menjalankan sistem dengan baik dan lancar disajikan pada Tabel 1.

Tabel 1. Kebutuhan perangkat keras

\begin{tabular}{|c|c|c|c|}
\hline No & Spesifikasi & Administrator & Pengguna \\
\hline 1 & Processor & intel Pentium 2,40 GHz & intel Pentiuml 2,0 Ghz \\
\hline 2 & Memory & DDR3 4Gb & DDR3 2Gb \\
\hline 3 & Monitor & $1024 \times 768$ & $1024 \times 768$ \\
\hline 4 & Jaringan internet & Up to $100 \mathrm{Mbps}$ & Up to $10 \mathrm{Mbps}$ \\
\hline 5 & Keyboard, mouse, printer dan modem/LAN/ Wi-Fi & Plug and Play & Plug and Play \\
\hline
\end{tabular}

Kebutuhan perangkat lunak yang dibutuhkan dalam membangun sistem informasi di SMAN Mojoagung adalah sistem operasi Windows 8 dan Linux Mint 17.3, serta web browser Google Chrome dan Mozilla Firefox. Koneksi jaringan yang ada saat ini di SMAN Mojoagung telah terhubung internet dengan kecepatan sampai $100 \mathrm{Mbps}$, sehingga dapat langsung mengakses sistem monitoring pada web hosting sekolah dengan baik. Level pengguna di SMAN Mojoagung terbagi menjadi tiga, yaitu administator, guru dan siswa yang sebagian besar sudah terbiasa menggunakan sistem informasi, sehingga telah memenuhi kriteria untuk dapat menggunakan sistem yang akan dibangun. Desain basis data sistem monitoring siswa yang diusulkan akan dirancang menggunakan Entity Relational Diagram (ERD).

\subsection{Planning}

Pada tahap planning adalah pembagian tugas teknis yang akan dilakukan, resiko yang kemungkinan terjadi, sumberdaya yang digunakan untuk membangun sistem, hasil produk yang ingin dicapai, estimasi waktu pengerjaan dan tracking progress sejauh mana sistem yang sedang dikerjakan.

\section{3. $\quad$ Modeling}

Pengembangan dan analisis kualitas sistem monitoring kegiatan belajar mengajar ... http://doi.org/10.26594/teknologi.v10i1.1941 Teknologi: Jurnal IImiah Sistem Informasi dengan lisensi CC BY NC SA. 
Analisis dan desain dalam tahap modelling. Hasil analisis pada tahapan sebelumnya lebih didetailkan dilanjutkan untuk dimodelkan dalam bentuk desain. Desain yang dibuat diantaranya adalah desain database, pemodelan perangkat lunak berupa DFD (Data Flow Diagram) karena pemrograman yang akan dilakukan bersifat terstruktur, dan desain user interface dari system yang diusulkan pada penelitian ini.

\subsection{Construction}

Pada tahap ini dilakukan pembuatan sistem yang diusulkan berupa pengkodean bersifat terstruktur menggunakan Bahasa pemrograman PHP dan database menggunakan MariaDB. Hasil dari sistem yang sudah dibuat dilakukan skenario uji coba dengan pengujian WebQEM. Hal ini didasarkan dari International Organization for Standarization (ISO) telah mengusulkan beberapa karakteristik untuk melakukan pengujian terhadap kualitas sebuah perangkat lunak. ISOStandar 9126 mengidentifikasikan enam karakteristik sebuah perangkat lunak dikatakan berkualitas yaitu: Functionality, reliability, usability, efficiency, maintability, dan portability (IEC, 2011). Pengujian sistem informasi monitoring siswa ini menggunakan turunan ISO Standard 9126 yaitu WebQEM yang lebih berfokus pada pengujian aplikasi berbasis web dan memiliki beberapa indikator pengujian, yaitu functionality, efficiency, reliability, dan usability (Kartiko \& Hertantyo, 2018). Aspek kriteria efficiency, reliability, dan usability untuk sistem informasi dipilih pada penelitian ini karena setiap aspek dapat menggunakan metode pengukuran yang berbeda (Sari, 2016). Dalam pengujian ini, aspek kriteria telah mewakili tiga orientasi penting, yaitu sistem informasi berbasis web, pengguna dan kehandalan server untuk melayani request dalam jumlah besar.

Aspek pengujian diantaranya efficiency, pengujian ini menggunakan alat ukur YSlow yang dikembangkan oleh Yahoo Developer Network dan Page Speed yang dikembangkan oleh Google Developer untuk mengukur performa efisiensi sebuah halaman web. Performa yang akan diukur adalah besarnya bytes data dokumen, jumlah HTTP request dan score akhir. Pengujian aspek reliability diuji menggunakan pengujian stress testing. Pengujian ini dilakukan menggunakan aplikasi JMeter untuk mengukur performa stress testing pada suatu web dengan parameter request, throughput dan error. Sedangkan aspek usability diukur menggunakan kuesioner. Pengujian ini menggunakan instrumen USE Questionnaire yang dibuat dalam bentuk skor lima poin dengan model skala likert.

\subsection{Maintenance}

Ketika sistem dijalankan mungkin saja masih ada error kecil yang tidak ditemukan sebelumnya, atau dimungkinkan pengembangan fitur-fitur yang belum ada pada sistem tersebut, untuk itu pemeliharaan sistem diperlukan, sehingga diharapkan dapat meningkatkan kualitas sistem pada versi terbaik.

\section{Hasil dan Pembahasan}

Pada bagian ini ditampilkan hasil dan pembahasan antarmuka sistem monitoring siswa beserta pengujian yang telah dilakukan. Gambar 4(a) adalah halaman login yang berfungsi untuk mengakses sistem monitoring siswa SMAN Mojoagung. Gambar 4(b) adalah halaman dashboard admin adalah antarmuka yang berisi nama akun masing-masing pengguna dan informasi jika terdapat kendala dalam penggunaan aplikasi. Gambar 5 adalah halaman yang bisa diakses oleh admin.

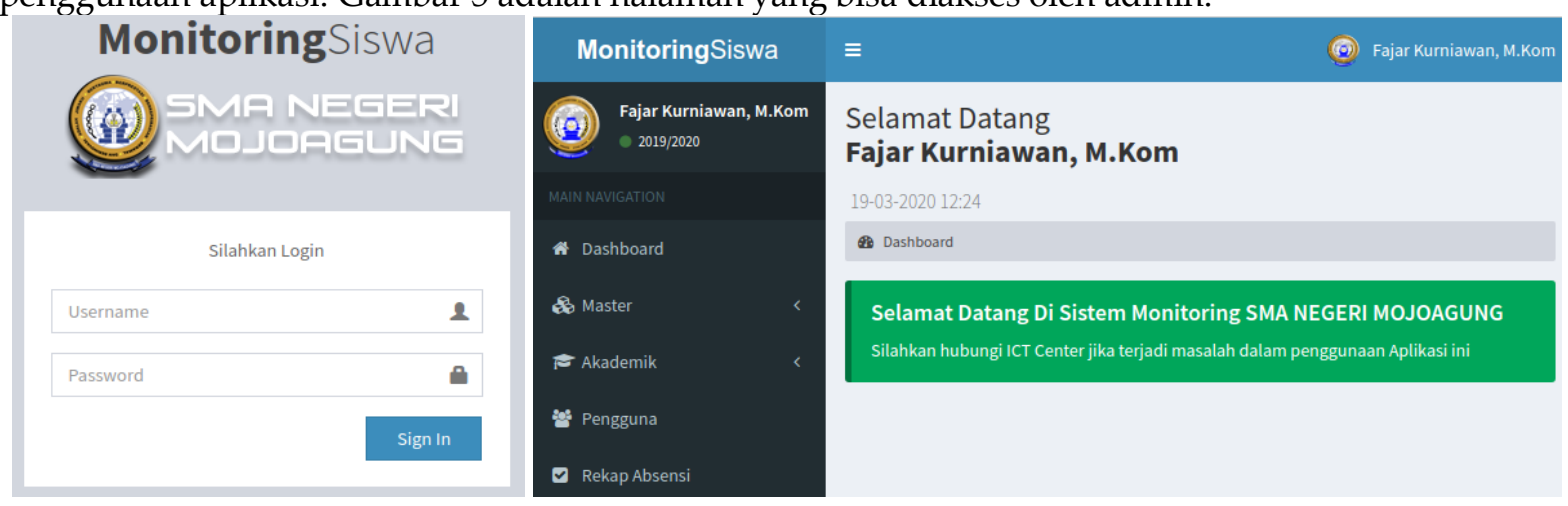

(a)

(b)

Gambar 4. Halaman: (a) Login; (b) Dashboard admin

Halaman data siswa dan guru yang ditunjukkan pada Gambar 5(a) dapat digunakan untuk mengelola data siswa dan guru, halaman ini memiliki fitur import untuk mempermudah memasukkan

Pengembangan dan analisis kualitas sistem monitoring kegiatan belajar mengajar ... http://doi.org/10.26594/teknologi.v10i1.1941 Teknologi: Jurnal IImiah Sistem Informasi dengan lisensi CC BY NC SA. 
data ke sistem monitoring siswa. Halaman data mata pelajaran yang ditunjukkan pada Gambar 5(b) dapat digunakan untuk mengelola data semua mata pelajaran yang diajarkan di SMAN Mojoagung. Halaman data kompetensi dasar yang ditunjukkan Gambar 5(c) dapat digunakan untuk mengelola data kompetensi dasar setiap mata pelajaran dan tingkat kelas yang dikelompokkan menjadi 2 semester.
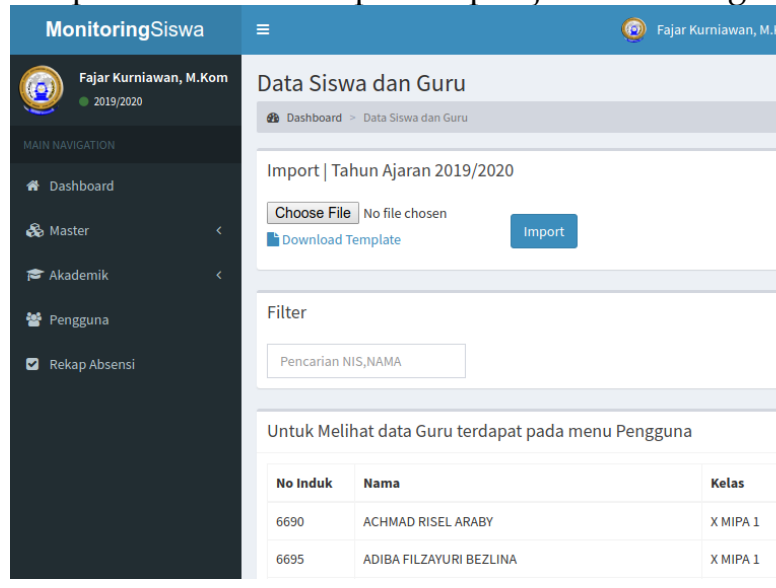

(a)
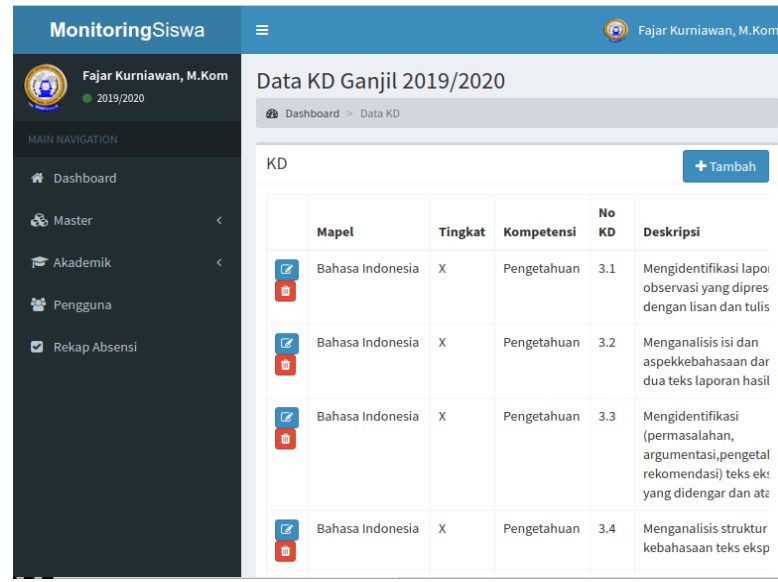

(c)

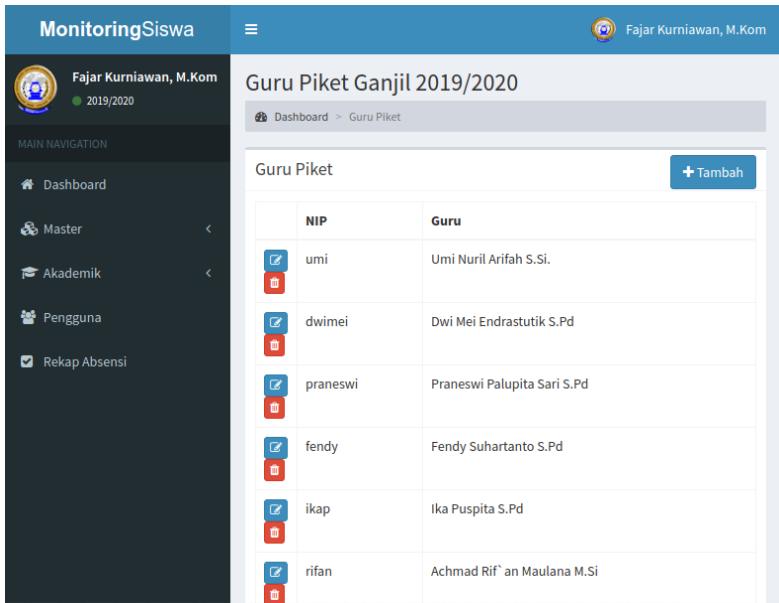

(e)
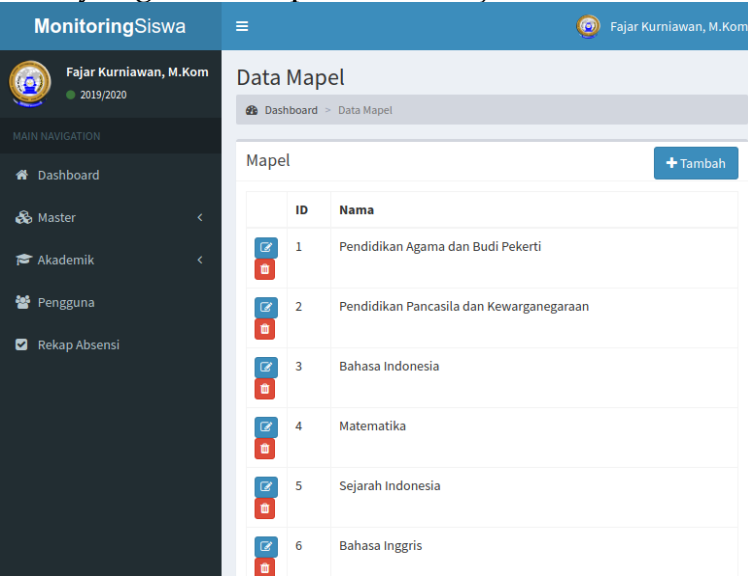

(b)

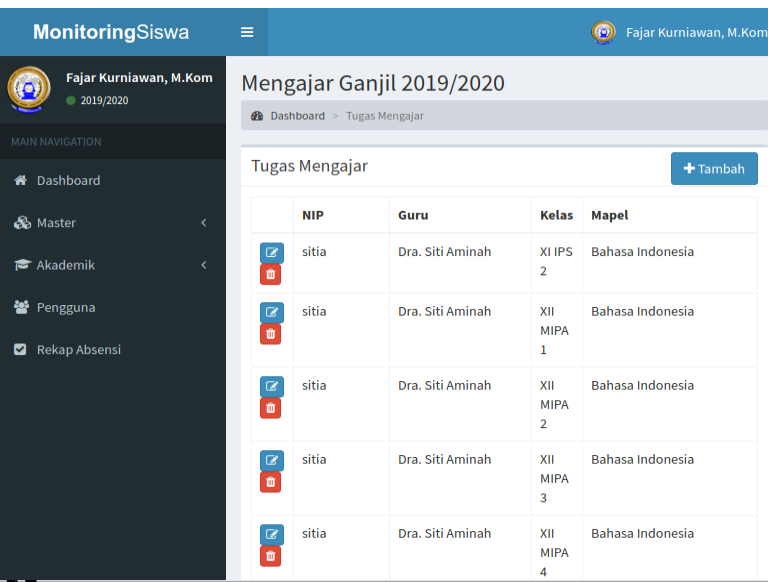

(d)

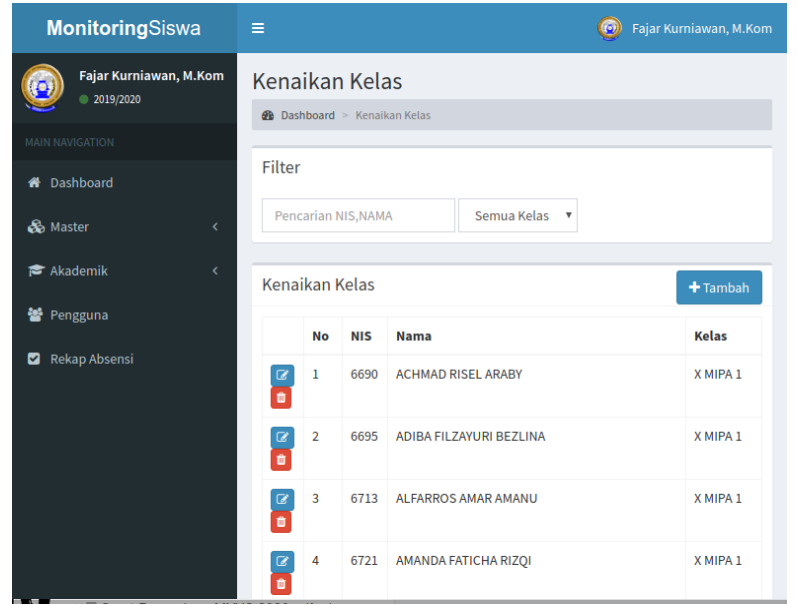

(f)

Gambar 5. Halaman: (a) Data siswa dan guru; (b) Data mata pelajaran; (c) Data kompetensi dasar; (d) Penugasan guru mengajar; (e) Penugasan guru piket; (f) Kenaikan kelas

Halaman penugasan guru mengajar yang ditunjukkan Gambar 5(d) dapat digunakan untuk mengelola tugas mengajar guru pada mata pelajaran apa dan di kelas berapa sesuai dengan surat keputusan mengajar di SMAN Mojoagung. Halaman penugasan guru piket yang ditunjukkan Gambar 5(e) dapat digunakan untuk mengelola guru piket yang bertugas. Halaman kenaikan kelas yang ditunjukkan Gambar 5(f) dapat digunakan untuk mengelola proses kenaikan kelas yang dilakukan pa- 
da awal tahun pelajaran.

Halaman beranda guru yang digunakan untuk mengelolah monitoring KBM, jurnal kelas, kehadiran siswa dan rekapitulasi kehadiran siswa. Untuk mengakses sistem informasi monitoring siswa, setiap guru dapat mengunakan username dan password yang telah diberikan oleh pihak sekolah. Gambar 6(a) berfungsi untuk mengelola monitoring KBM dalam bentuk import nilai kompetensi dasar. Sebelumnya guru mengunduh template import nilai, setelah diisi nilai per kompetensi dasar, kemudian mengimpor file ke dalam sistem dan ditampilkan oleh sistem di akun masing-masing guru. Halaman input jurnal mengajar yang ditunjukkan Gambar 6(b) dapat digunakan untuk mengelola data jurnal mengajar yang meliputi kelas, kegiatan, waktu, tanggal dan deskripsi kompetensi dasar yang dilakukan guru setiap kali masuk ke dalam kelas.

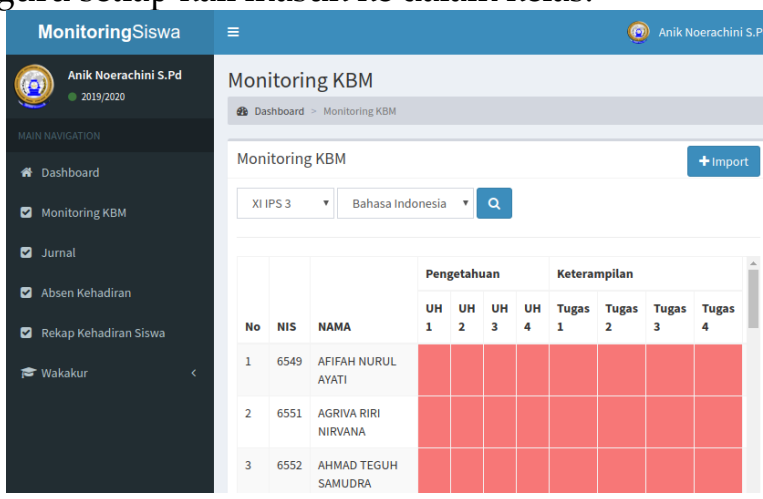

(a)

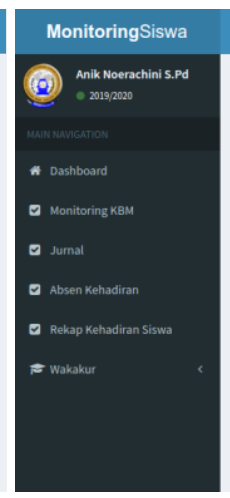

Gambar 6. Halaman: (a) Monitoring KBM; (b) Input jurnal mengajar

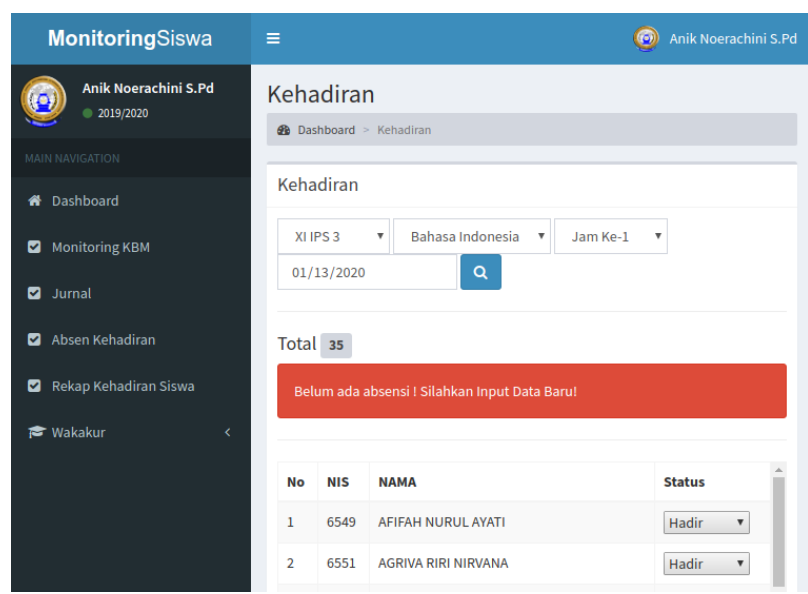

(a)

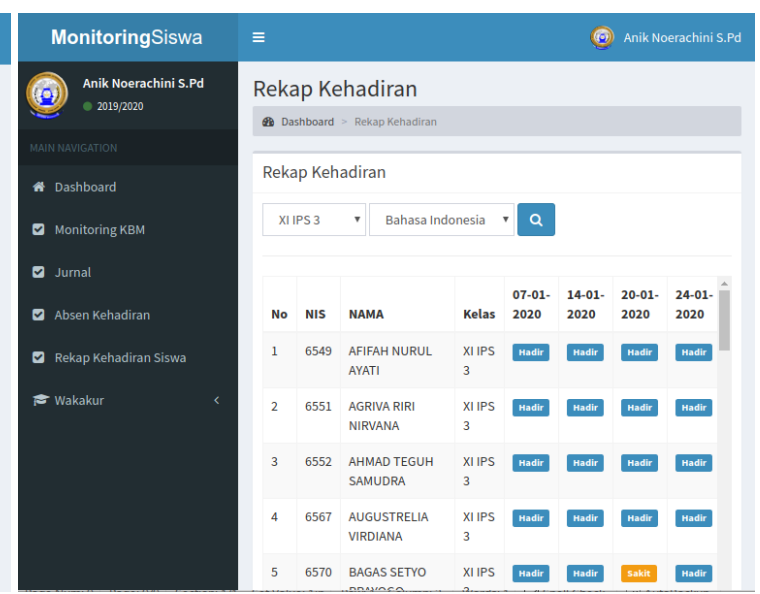

(b)

Gambar 7. Halaman: (a) Input kehadiran siswa; (b) Rekap kehadiran siswa

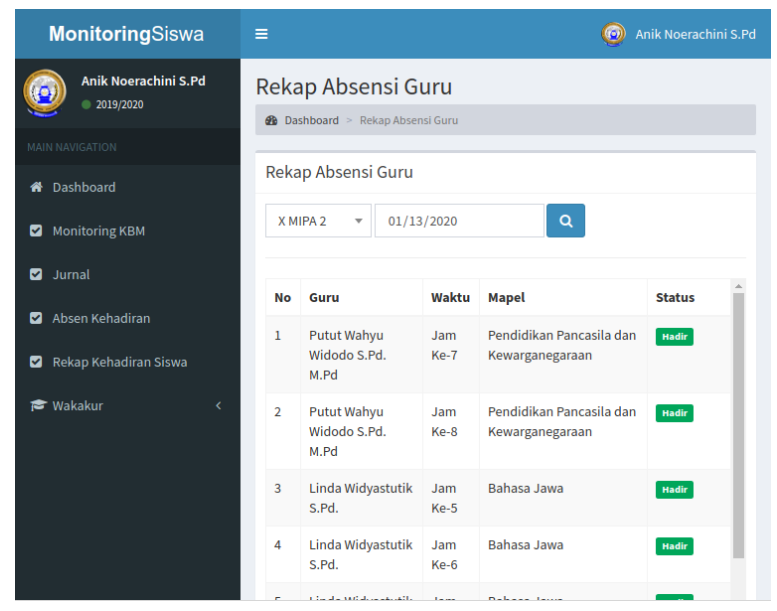

Gambar 8. Halaman rekap kehadiran guru 
Halaman input kehadiran siswa yang ditunjukkan Gambar 7(a) dapat digunakan untuk mengelola kehadiran siswa setiap mata pelajaran, di mana guru melakukan absensi terhadap kelas yang diajar dengan memberikan status hadir, terlambat, sakit, ijin atau alpa pada setiap siswa. Pada sistem, secara default sudah terisi status hadir, sehingga mempermudah guru untuk memberikan status ketidakhadiran bagi siswa yang tidak hadir saja. Halaman input kehadiran siswa yang ditunjukkan Gambar 7(b) dapat digunakan untuk memberikan informasi rekapitulasi tanggal status kehadiran siswa pada mata pelajaraan yang diampu masing-masing guru.

Halaman beranda wakil kepala sekolah bidang kurikulum yang digunakan untuk mengelola data rekapitulasi kehadiran guru. Gambar 8 adalah tampilan fitur khusus wakil kepala sekolah bidang kurikulum yang digunakan untuk monitoring guru terkait kehadiran mengajar. Status kehadiran guru ini diperoleh, jika jurnal telah diisi oleh masing-masing guru mata pelajaran ketika guru mengajar di kelas.

Halaman beranda siswa yang digunakan untuk mengelola data biodata siswa yang mengunakan akun masing-masing dalam sistem informasi ini. Pada halaman siswa terdapat 3 fitur utama yaitu melihat data nilai melalui monitoring KBM, progres kompetensi dasar setiap mata pelajaran dan status kehadiran masing-masing siswa.

Halaman data jurnal mengajar guru yang ditunjukkan Gambar 9(a) memiliki fungsi, siswa dapat melihat progres kompetensi dasar setiap mata pelajaran yang telah diajarkan. Halaman data kehadiran siswa yang ditunjukkan Gambar 9(b) memiliki fungsi, siswa dapat melihat status kehadiran masingmasing siswa tiap mata pelajaran. Halaman data monitoring KBM yang ditunjukkan Gambar 9(c) memiliki fungsi, siswa dapat melihat data nilai setiap mata pelajaran pada kompetensi dasar yang telah ditentukan dan diimpor oleh masing-masing guru.

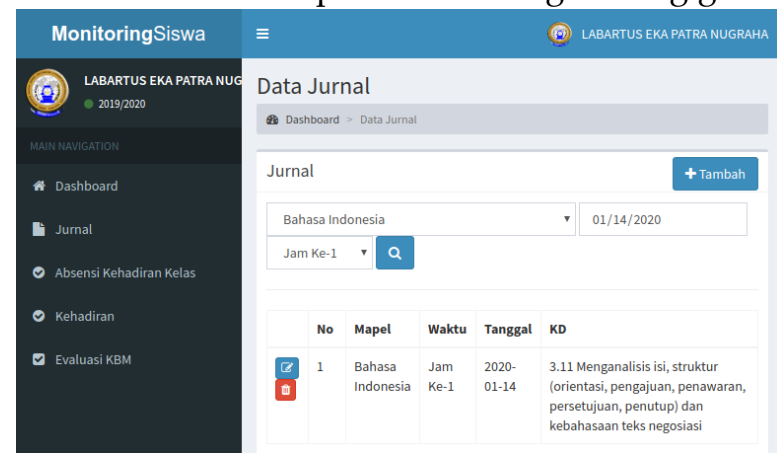

(a)

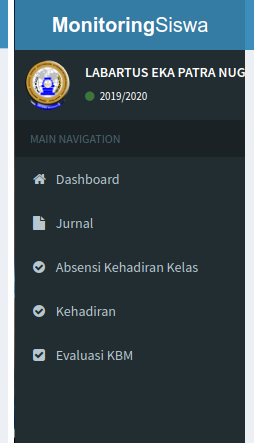

(1)

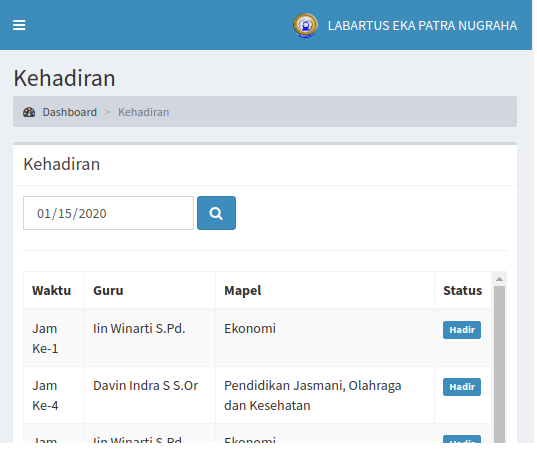

(b)

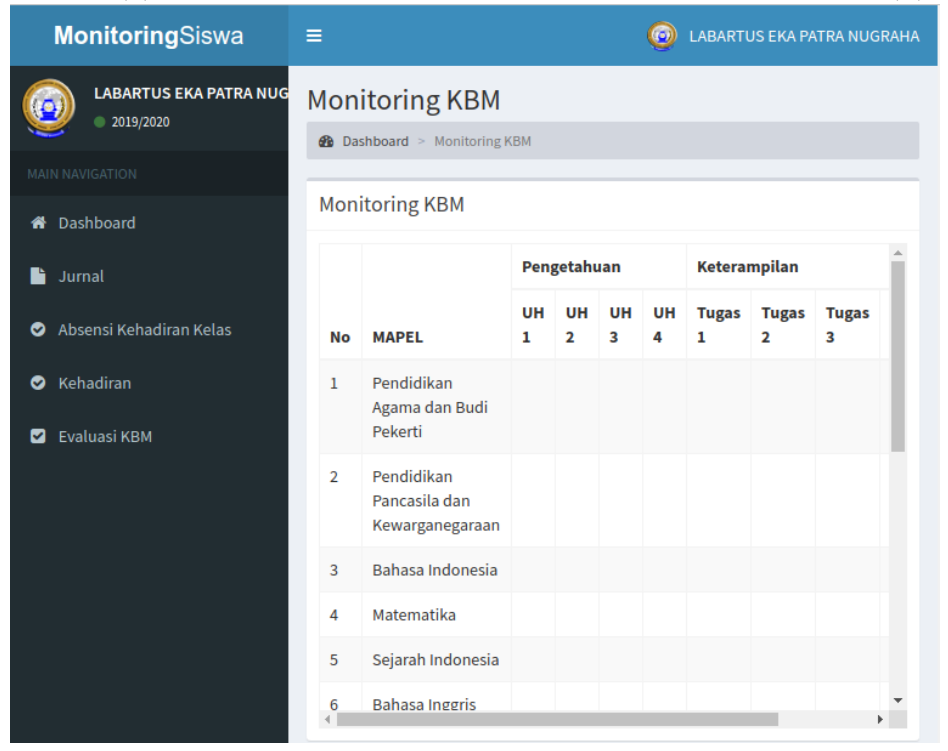

(c)

Gambar 9. Halaman: (a) Data jurnal mengajar guru; (b) Data kehadiran siswa; (c) Data monitoring KBM pada siswa 


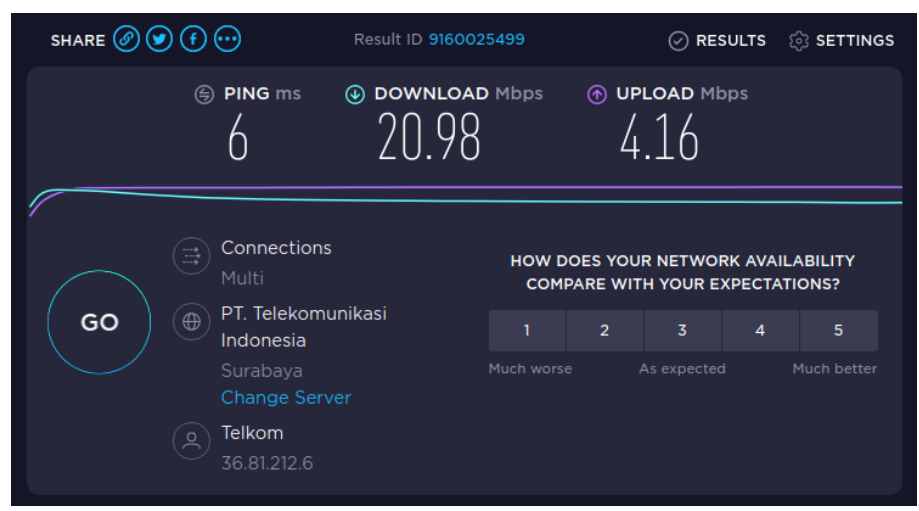

Gambar 10. Trafik kecepatan internet

Pengujian pertama menggunakan aspek kriteria efficiency, reliability, dan usability berdasarkan WebQEM. Pengujian dilakukan menggunakan kecepatan internet Indihome paket Phonix dan browser Google Chrome yang diukur menggunakan aplikasi SpeedTest (Ookla, 2020) yang dapat dilihat pada Gambar 10.

Aspek efficiency dilakukan pengujian dengan dua alat bantu dalam penelitian ini, yaitu Google PageSpeed Insights (Insights, 2020) dan GTMetrix (Fryonanda \& Ahmad, 2017). Pengujian dilakukan dengan cara memasukkan satu per satu link di dalam sistem monitoring untuk dilakukan pengujian efficiency. Secara umum, hasil pengujian sistem informasi monitoring siswa SMAN Mojoagung ditunjukkan pada Tabel 2 dan Tabel 3.

Tabel 2. Hasil uji efficiency (Google PageSpeed Insights)

\begin{tabular}{clcccc}
\hline No & \multicolumn{1}{c}{ Halaman } & FCP & SI & TOI & Score \\
\hline 1 & Login & 0,6 & 0,6 & 0,8 & 100 \\
2 & Dashboard & 0,8 & 0,8 & 0,8 & 98 \\
3 & Tahun Pelajaran & 0,8 & 0,8 & 0,8 & 98 \\
4 & Data Siswa dan Guru & 0,8 & 0,8 & 0,8 & 98 \\
5 & Data Kelas & 0,7 & 0,7 & 0,7 & 99 \\
6 & Data Mapel & 0,6 & 0,6 & 0,6 & 100 \\
7 & Set KD & 0,8 & 0,9 & 0,9 & 98 \\
8 & Tugas Mengajar & 0,8 & 1 & 0,9 & 98 \\
9 & Guru Piket & 0,8 & 0,8 & 0,8 & 98 \\
10 & Ketua Kelas & 0,8 & 0,8 & 0,8 & 98 \\
11 & Wakakur & 0,8 & 0,9 & 0,8 & 98 \\
12 & Kenaikan Kelas & 0,8 & 0,8 & 0,9 & 98 \\
13 & Pengguna & 0,8 & 0,8 & 0,8 & 98 \\
14 & Login & 0,6 & 0,6 & 0,8 & 100 \\
15 & Dashboard & 0,6 & 0,8 & 0,6 & 99 \\
16 & Monitoring KBM & 0,8 & 0,8 & 0,8 & 98 \\
17 & Jurnal & 0,8 & 0,9 & 0,8 & 98 \\
18 & Absensi Siswa & 0,8 & 0,9 & 0,8 & 98 \\
19 & Rekap Absensi Siswa & 0,8 & 0,9 & 0,9 & 98 \\
20 & Absensi Guru & 0,8 & 0,8 & 0,8 & 99 \\
21 & Login & 0,8 & 0,8 & 0,8 & 99 \\
22 & Dashboard & 0,6 & 0,8 & 0,9 & 99 \\
23 & Jurnal & 0,6 & 1,1 & 0,6 & 98 \\
24 & Kehadiran & 0,8 & 0,8 & 0,9 & 98 \\
25 & Evaluasi KBM & 0,7 & 0,8 & 0,9 & 99 \\
\hline & Rata-Rata & $\mathbf{0 , 7 4}$ & $\mathbf{0 , 8 1}$ & $\mathbf{0 , 8}$ & $\mathbf{9 8 , 4 8}$ \\
\hline
\end{tabular}

Pada Tabel 2, FCP (First Contentful Paint) adalah indikator yang mengukur waktu mulai dari awal saat halaman ditampilkan hingga semua konten halaman ditampilkan. SI (Speed Index) adalah indikator yang mengukur seberapa cepat konten ditampilkan secara visual selama pemuatan halaman. TOI (Time to Interactive) adalah indikator yang mengukur waktu respon input pengguna dengan andal dengan cepat, dari awal saat halaman ditampilkan hingga semua konten ditampilkan.

Hasil pengujian efficiency menggunakan Google PageSpeed Insights diperoleh kesimpulan, bahwa efisiensi sistem monitoring siswa masuk dalam kategori cepat dengan score 98,48. Dasar kategori Pengembangan dan analisis kualitas sistem monitoring kegiatan belajar mengajar ... http://doi.org/10.26594/teknologi.v10i1.1941 Teknologi: Jurnal IImiah Sistem Informasi dengan lisensi CC BY NC SA. 
score Google PageSpeed Insights sebagai berikut: 0-49 (slow): Red, 50-89 (average): Orange, dan 90-100 (fast): Green. Sedangkan dari hasil pengujian efficiency menggunakan GTMetrix diperoleh kesimpulan bahwa efisiensi sistem monitoring siswa masuk dalam grade A dengan performance score $99 \%$ dari nilai tertinggi $100 \%$, sehingga rata-rata load time yang didapatkan memenuhi uji aspek efficiency ketika $95 \%$ access request kurang dari 4 detik, sesuai aturan pada GTMetrix sendiri. Dasar grade sesuai rekomendasi Yahoo Developer Network sabagai berikut score 90-100: Grade A, score 80-89: Grade B, score 70 - 79: Grade C, dan score < 69: Grade D.

Pengujian aspek reliability menggunakan aplikasi JMeter 5.2.1 untuk mengukur performa stress testing pada suatu web (Delta \& Asmunin, 2016). Skenario yang dilakukan untuk pengujian menggunakan 600 user melakukan akses secara bersamaan dalam rentang waktu 3 menit, hal ini didasarkan pada jumlah pengguna yang melakukan akses bersamaan di SMAN Mojoagung, dan ratarata melakukan akses pada sistem monitoring selama 3 menit. Hasil pengujian menggunakan JMeter ditunjukkan oleh Gambar 11 dan Tabel 4. Perlu diketahui bahwa semakin besar nilai throughput, menunjukkan kemampuan server menangani permintaan yang besar dan berat. Sehingga dapat disimpulkan dari Gambar 11 dan Tabel 4, server memiliki performa yang baik karena mampu mengakomodasi 600 user, yang menangani 1.085 request dan throughput 227,098/menit dengan 0\% error dari total 5.322 data yang tersimpan. sehingga dapat dikatakan memenuhi kriteria standar reliability yang ditetapkan dalam standar Telcordia (Asthana \& Olivieri, 2009).

Tabel 3. Hasil pengujian efficiency (GTMetrix)

\begin{tabular}{|c|c|c|c|c|c|}
\hline No & Halaman & $\begin{array}{c}\text { FLT } \\
\text { (s) }\end{array}$ & $\begin{array}{l}\text { TPS } \\
\text { (kB) }\end{array}$ & $\begin{array}{c}\text { Request } \\
\text { (per } \\
\text { buah) }\end{array}$ & $\begin{array}{c}\text { Score } \\
(\%)\end{array}$ \\
\hline 1 & Login & 2,3 & 187 & 16 & 99 \\
\hline 2 & Dashboard & 3,5 & 191 & 17 & 99 \\
\hline 3 & Tahun Pelajaran & 2,6 & 191 & 17 & 99 \\
\hline 4 & Data Siswa dan Guru & 3,4 & 191 & 17 & 99 \\
\hline 5 & Data Kelas & 3,3 & 191 & 17 & 99 \\
\hline 6 & Data Mapel & 2,7 & 191 & 17 & 99 \\
\hline 7 & Set KD & 2,6 & 191 & 17 & 99 \\
\hline 8 & Tugas Mengajar & 2,9 & 191 & 17 & 99 \\
\hline 9 & Guru Piket & 2,6 & 191 & 17 & 99 \\
\hline 10 & Ketua Kelas & 4,2 & 191 & 17 & 99 \\
\hline 11 & Wakakur & 3,1 & 191 & 17 & 99 \\
\hline 12 & Kenaikan Kelas & 2,7 & 191 & 17 & 99 \\
\hline 13 & Pengguna & 2,7 & 191 & 17 & 99 \\
\hline 14 & Login & 2,4 & 187 & 16 & 99 \\
\hline 15 & Dashboard & 2,6 & 191 & 17 & 99 \\
\hline 16 & Monitoring KBM & 3,4 & 191 & 17 & 99 \\
\hline 17 & Jurnal & 2,5 & 191 & 17 & 99 \\
\hline 18 & Absensi Siswa & 2,4 & 191 & 17 & 99 \\
\hline 19 & Rekap Absensi Siswa & 2,6 & 191 & 17 & 99 \\
\hline 20 & Absensi Guru & 2,4 & 191 & 17 & 99 \\
\hline 21 & Login & 2,3 & 187 & 16 & 99 \\
\hline 22 & Dashboard & 2,8 & 191 & 17 & 99 \\
\hline 23 & Jurnal & 2,6 & 191 & 17 & 99 \\
\hline 24 & Kehadiran & 2,4 & 191 & 17 & 99 \\
\hline 25 & Evaluasi KBM & 2,4 & 191 & 17 & 99 \\
\hline \multicolumn{2}{|r|}{ Rata-Rata } & 2,78 & 190,52 & 16,88 & 99 \\
\hline
\end{tabular}

Pada Tabel 3, FLT (Fully Loaded Time) adalah waktu yang dibutuhkan untuk menampilkan seluruh halaman dalam satuan detik (sekon, s). TPS (Total Page Size) adalah total besarnya ukuran file dari seluruh halaman yang ditampilkan dalam satuan kilobyte $(\mathrm{kB})$. Request adalah jumlah permintaan dari seluruh halaman yang ditampilkan dalam satuan buah (bh). 
Tabel 4. Hasil pengujian Jmeter

\begin{tabular}{cccc}
\hline User & Error \% & HTTP Request & Throughput \\
\hline 600 & 0 & 1085 & 227,098 \\
\hline
\end{tabular}

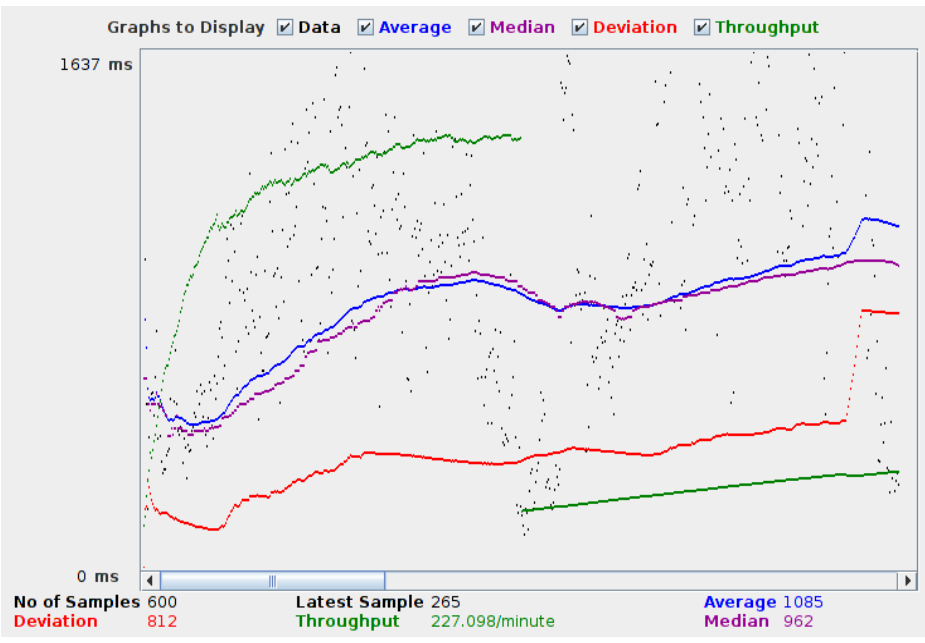

Gambar 11. Hasil pengujian Jmeter

Pengujian aspek penerimaan usability dilakukan dengan pemberian kuesioner yang bertujuan untuk mendukung data yang telah didapat dari skenario pengujian, di mana nantinya akan diolah dan menghasilkan suatu kesimpulan bagi penelitian. Tingkat usability menjadi tolak ukur, apakah sistem tersebut akan bermanfaat, dapat diterima oleh pengguna dan bertahan lama di pasaran (Ola, Suyoto, \& Purnomo, 2016).

Pengujian menggunakan instrumen USE Questionnaire yang dibuat dalam bentuk skor lima poin dengan model skala likert (Rahman \& Vitalocca, 2018) Kuesioner berisi pertanyaan seputar kesan responden saat menggunakan sistem. Kuesioner terdiri dari 13 pertanyaan dengan 322 responden dari siswa dan guru SMAN Mojoagung. Tabel 5 adalah data yang didapat dari hasil kuesioner.

Tabel 5. Data pengujian pertanyaan

\begin{tabular}{lccccc}
\hline \multicolumn{1}{c}{ Pertanyaan } & $\mathbf{1}$ & $\mathbf{2}$ & $\mathbf{3}$ & $\mathbf{4}$ & $\mathbf{5}$ \\
\hline 1. Apakah tampilan antarmuka MonSys mudah di kenali? & 11 & 28 & 91 & 109 & 83 \\
2. Apakah MonSys mudah dioperasikan? & 8 & 16 & 77 & 116 & 105 \\
3. Apakah tampilan warna pada MonSys nyaman dilihat dan tidak & & & & & \\
$\quad$ membosankan? & 12 & 23 & 87 & 114 & 86 \\
4. Apakah tampilan menu dalam MonSys mudah dikenali? & 6 & 17 & 100 & 107 & 92 \\
5. Apakah informasi dalam MonSys mudah dicari? & 6 & 25 & 84 & 116 & 91 \\
6. Apakah tulisan yang ada mudah dibaca? & 9 & 20 & 72 & 91 & 130 \\
7. Apakah aplikasi mudah diunduh? & 6 & 22 & 98 & 115 & 81 \\
8. Apakah simbol, ikon dan gambar yang ada mudah dipahami? & 6 & 11 & 89 & 131 & 85 \\
9. Apakah mudah mengakses informasi yang ditawarkan? & 2 & 18 & 84 & 131 & 87 \\
10. Apakah fungsi yang ditawarkan sesuai dengan tujuan aplikasi? & 2 & 14 & 91 & 121 & 94 \\
11. Apakah informasi yang tersedia mudah diakses? & 3 & 14 & 80 & 128 & 97 \\
12. Apakah keamanan aplikasi sudah terjamin? & 6 & 22 & 109 & 117 & 68 \\
13. Apakah menu dan tampilan MonSys mudah diingat? & 6 & 18 & 74 & 129 & 95 \\
\hline \multicolumn{1}{c}{ Total } & $\mathbf{8 3}$ & $\mathbf{2 4 8}$ & $\mathbf{1 . 1 3 6}$ & $\mathbf{1 . 5 2 5}$ & $\mathbf{1 . 1 9 4}$ \\
\hline
\end{tabular}

MonSys pada Tabel 5 dan Tabel 6 adalah kepanjangan dari sistem yang diusulkan yaitu Monitoring system. Hasil sebaran kuesioner yang disajikan pada Tabel 5, dapat dilakukan penghitungan seperti pada Tabel 6. Persamaan yang digunakan adalah Persamaan 1 untuk menghasilkan persentase uji data.

Presentase Uji $=\frac{\text { Hasil Yang Diperoleh }}{\text { Hasil Maksimal }} \times 100 \%$

Berdasarkan hasil penghitungan akhir diperoleh persentase $76,72 \%$ dalam pengujian usability. Skor tersebut menunjukkan bahwa kualitas perangkat lunak dari aspek usability telah sesuai dan jika di 
interpretasikan dengan skala likert termasuk kategori baik.

Tabel 6. Penghitungan data pengujian

\begin{tabular}{|c|c|c|c|}
\hline Pertanyaan & $\begin{array}{l}\text { Skor } \\
\text { Total }\end{array}$ & $\begin{array}{c}\text { Skor } \\
\text { Maksimal }\end{array}$ & $\begin{array}{l}\text { Persentase } \\
\%\end{array}$ \\
\hline 1. Apakah tampilan antarmuka MonSys mudah di kenali? & 1.191 & 1.610 & 73,98 \\
\hline 2. Apakah MonSys mudah dioperasikan? & 1.260 & 1.610 & 78,26 \\
\hline $\begin{array}{l}\text { 3. Apakah tampilan warna pada MonSys nyaman dilihat dan } \\
\text { tidak membosankan? }\end{array}$ & 1.205 & 1.610 & 74,84 \\
\hline 4. Apakah tampilan menu dalam MonSys mudah dikenali? & 1.228 & 1.610 & 76,27 \\
\hline 5. Apakah informasi dalam MonSys mudah dicari? & 1.227 & 1.610 & 76,21 \\
\hline 6. Apakah tulisan yang ada mudah dibaca? & 1.279 & 1.610 & 79,44 \\
\hline 7. Apakah aplikasi mudah diunduh? & 1.209 & 1.610 & 75,09 \\
\hline 8. Apakah simbol, ikon dan gambar yang ada mudah dipahami? & 1.244 & 1.610 & 77,27 \\
\hline 9. Apakah mudah mengakses informasi yang ditawarkan? & 1.249 & 1.610 & 77,58 \\
\hline $\begin{array}{l}\text { 10. Apakah fungsi yang ditawarkan sesuai dengan tujuan } \\
\text { aplikasi? }\end{array}$ & 1.257 & 1.610 & 78,07 \\
\hline 11. Apakah informasi yang tersedia mudah diakses? & 1.268 & 1.610 & 78,76 \\
\hline 12. Apakah keamanan aplikasi sudah terjamin? & 1.185 & 1.610 & 73,60 \\
\hline 13. Apakah menu dan tampilan MonSys mudah diingat? & 1.255 & 1.610 & 77,95 \\
\hline Total & 16.057 & 20.930 & 76,72 \\
\hline
\end{tabular}

Dari hasil pengujian dapat disimpulkan bahwa sistem informasi monitoring siswa SMAN Mojoagung telah memiliki aspek nilai usability yang baik dan layak digunakan untuk mendukung pengelolaan akademik siswa karena sistem tersebut telah lolos dalam uji usability.

\section{Kesimpulan}

Berdasarkan hasil pengujian yang telah dilakukan, maka sistem informasi yang diusulkan telah mengakomodasi jurnal kelas, monitoring absensi per mata pelajaran, serta kompetensi dasar pembelajaran pada setiap aspek kegiatan proses belajar mengajar di SMAN Mojoagung. Guru piket juga dapat mengetahui data siswa yang belum hadir pada jam pertama, sehingga mempermudah guru piket melakukan pelaporan harian. Terakomodasinya kebutuhan berupa fitur pada sistem yang diusulkan, tentunya mengurangi dokumen versi cetak dari sisi administrasi akademik dan waktu yang dibutuhkan lebih cepat dalam proses pencarian data, rekapitulasi data dan pengelolaan lainnya yang selama ini dilakukan setiap semester. Sistem yang diusulkan ini dapat memberikan informasi secara realtime.

Pengujian sistem informasi monitoring siswa ini menggunakan turunan ISO Standard 9126 yaitu WebQEM yang lebih berfokus pada pengujian aplikasi berbasis web dan memiliki beberapa indikator pengujian, yaitu efficiency, reliability, dan usability. Sistem juga dapat memberikan laporan rekapitulasi kehadiran siswa, laporan perkembangan kompetensi dasar per mata pelajaran yang telah diselesaikan serta laporan nilai siswa dalam bentuk monitoring KBM. Adanya sistem yang diusulkan dapat diketahui bahwa pengujian sistem yang dilakukan menggunakan uji eficiency memperoleh hasil pengujian yakni rata-rata loadtime 2,78 detik dan rata-rata total page size 190,52 KB pada kecepatan internet 20,98 Mbps. Sedangkan pengujian berdasarkan aspek reliability, server memiliki hasil performa yang baik karena mampu menangani 600 user dan melayani 1.085 request serta throughput 227,098/menit dengan $0 \%$ error dari total 5.322 data yang tersimpan. Dari sisi pengujian penerimaan usability, sistem informasi monitoring siswa SMAN Mojoagung telah memiliki aspek usability yang baik dan layak digunakan untuk mendukung pengelolaan akademik berdasarkan analisis perhitungan akhir diperoleh persentase $76,72 \%$.

Beberapa saran untuk pengembangan sistem informasi monitoring siswa ini yang dapat dijadikan referensi untuk penelitian kedepan adalah mengintegrasikan sistem monitoring siswa ini dengan sistem informasi akademik yang terdapat di sekolah agar data siswa dapat langsung diakses tanpa melakukan penginputan ulang oleh administrator. Adanya notifikasi kehadiran yang berbasis mobile untuk 
mempermudah informasi baik dari siswa maupun sekolah sehingga akses informasi dapat diterima dengan lebih baik. Perlu adanya optimalisasi tampilan pengguna agar sistem lebih menarik berdasarkan prinsip kegunaannya serta dengan model pengujian kualitas yang lebih variatif sehingga mampu menghasilkan tingkat akurasi pengujian yang lebih baik dan pengujian security testing untuk meningkatkan keamanan data pada sistem informasi monitoring di masa yang akan datang.

\section{Referensi}

Delta, E. N., \& Asmunin, A. (2016). Performance Test Dan Stress Website Menggunakan Open Source Tools. Jurnal Manajemen Informatika, 6(1), 208-215.

Firmansyah, R. (2018). Usability Testing Dengan Use Questionnaire Pada Aplikasi Sipolin Provinsi Jawa Barat. Swabumi (Suara Wawasan Sukabumi): Ilmu Komputer, Manajemen, dan Sosial, 6(1), 1-7.

Fryonanda, H., \& Ahmad, T. (2017). Analisis Website Perguruan Tinggi Berdasarkan Keinginan Search Engine Menggunakan Automated Software Testing GTmetrix. Kalbiscientia: Jurnal Sains dan Teknologi, 4(2), 179-183.

Hakim, A., Saragih, H., \& Suharto, A. (2015). Evaluasi Tata Kelola Teknologi Informasi Dengan Framework Cobit 5 Di Kementerian ESDM (Studi Kasus p ada Pusat Data dan Teknologi Informasi ESDM. Jurnal Sistem Informasi (Journal of Information System), 10(2).

IEC, I. (2011). ISO/IEC 25010:2011- Systems and software engineering - Systems and software Quality Requirements and Evaluation (SQuaRE) - System and software quality models. London, UK: BSI.

Insights, P. (2020). Tentang PageSpeed Insights. Retrieved from PageSpeed Insights: https://developers.google.com/speed/docs/insights/about?hl=id

Kartiko, C., \& Hertantyo, G. B. (2018). Peningkatan Kualitas Aplikasi Pemantau Media Sosial dan Media Daring Menggunakan Metode WebQEM. JNTETI (Jurnal Nasional Teknik Elektro dan Teknologi Informasi), 7(2), 144-149.

Ola, Y. Y., Suyoto, S., \& Purnomo, S. (2016). Pengujian Usability Antarmuka Aplikasi Mangente. Seminar Nasional Teknologi Informasi dan Komunikasi 2016 (SENTIKA 2016) (pp. 334-342). Yogyakarta: Universitas Atma Jaya Yogyakarta.

Ookla, O. (2020). Speedtest. Retrieved from Speedtest: https://www.speedtest.net

Pressman, R. S., \& Maxim, B. R. (2015). Software Engineering: A Practitioners Approach (8th ed. ed.). New York: McGraw-Hill Education.

Putri, M. E., \& Wulandari, D. A. (2016). Sistem Informasi Monitoring Siswa Berbasis Web Dan SMS Gateway Pada SMK Negeri 37 Jakarta. Jurnal Teknik Komputer AMIK BSI, 2(2), 49-55.

Rahman, E. S., \& Vitalocca, D. (2018). Analisis Usabilitas Menggunakan Use Questionnaire Pada Sistem Informasi Smk Negeri 3 Makassar. Jurnal MEKOM: Media Komunikasi Pendidikan Kejuruan, 15(1), 1622.

Sari, S. K., Remawati, D., \& Widada, B. (2017). Sistem Informasi Monitoring dan Evaluasi Belajar Siswa Berbasis Web dan SMS Gateway di SDIT Nurul Istiqlal Klaten. Jurnal Ilmiah Sinus, 15(1), 59-70.

Sari, T. N. (2016). Analisis Kualitas dan Pengembangan Sistem Informasi Akademik Berbasis Web Menggunakan Standard ISO 9126. Jurnal Informatika dan Komputer (JIKO), 1(1).

Sutinah, E., Azima, G. N., \& Imaduddin, E. F. (2018). Sistem Informasi Monitoring Akademik Dan Prestasi Siswa Dengan Metode Waterfall. JIEET (Journal of Information Engineering and Educational Technology), 2(1), 47-59.

Utomo, B. (2017). Sistem Pemantauan Siswa Sekolah Berbasis Web(Studi Kasus :Pondok Pesantren Darul Muttaqien). Jurnal Online Mahasiswa (Jom) Bidang Ilmu Komputer/Informatika.

Yaqin, A. (2019). Sistem Informasi Monitoring Dan Evaluasi Bidikmisi. Jurnal Teknologi Informasi dan Ilmu Komputer (JTIIK), 6(4), 407-412. 